\title{
A temporally graded ECS function following one-trial learning'
}

ABRAHAM A. SPEVACK, RONALD G. RABEDEAU ${ }^{2}$ AND MARIKA E. SPEVACK QUEEN'S UNIVERSITY, KINGSTON, ONTARIO

In two experiments rats were shocked in the smaller chamber of a two-compartment apparatus. ECS effects on subsequent latencies were inversely related to shock-ECS intervals, in contrast to previous studies which found no such gradient.

Numerous studies (e.g., Heriot \& Coleman, 1962; McGaugh \& Madsen, 1964) have shown that electroconvulsive shock (ECS) administered within approximately $1 \mathrm{~h}$ after one-trial passive avoidance learning reduces the effect of the punishment in an amount inversely related to the learning-ECS time interval. Burěs \& Burěsová (1963) have reported a study in which the usual gradient was not obtained. Their rats received shock in one compartment of a two-compartment box and were then given ECS. The ECS was equally effective in reducing avoidance $1 \mathrm{~min}$ and $6 \mathrm{~h}$ after the learming trial. Chorover \& Schiller (1966) reported similar results. The study described here, using much the same procedure and apparatus as Burěs \& Burěsová (1963) and Chorover \& Schiller (1966), yielded results which show that the ECS effect is a decreasing function of the learning-ECS interval.

\section{EXPE RIMENT 1}

\section{Subjects}

The Ss were 133 male Sprague-Dawley rats obtained from the Canadian Breeding Laboratories at about 60 days of age. For the duration of the experiment Ss were individually housed and kept on ad lib food and water.

\section{Apparafus}

The apparatus was similar to that described by Burěs and Burésová (1963). It consisted of two chambers separated by a guillotine door. The smaller black chamber was 3 in. wide by 12 in. long and 16 in. high with a metal floor through which shock could be delivered. The other large white compartment was 18 in. on each dimension. A $100 \mathrm{~W}$ spot lamp was suspended 24 in. above the center of the large chamber floor. Procedure

On the first day, Ss were handled for approximately 5 min each, during which the ECS clips were attached and removed several times. Approximately $24 \mathrm{~h}$ later Ss were allowed individually to explore both chambers of the apparatus for $3 \mathrm{~min}$ with the ECS ear clips attached. On the following two days Ss were placed into the large compartment and removed from the apparatus $10 \mathrm{sec}$ after they placed all four feet in the small compartment. On the treatment day Ss, wearing ear clips, were placed directly into the small compartment. A shock control group consisting of 19 Ss received foot shock and were removed $10 \mathrm{sec}$ later. Five groups consisting of 19 Ss each similarly received a foot shock followed by an ECS inside the small compartment $0.5 \mathrm{sec}, 5 \mathrm{~min}, 45 \mathrm{~min}$, or $2 \mathrm{~h}$ later. The intensity of the foot shock was $5 \mathrm{~mA}$, of the ECS $70 \mathrm{~mA}$, each delivered for $0.2 \mathrm{sec}$. Approximately $24 \mathrm{~h}$ after treatment tests were run with procedures identical to the two pretreatment tests.

Results

Table 1 shows the mean latencies of entering the small compartment after treatment. Examination of the means reveals that ECS effect on latencies was a decreasing function of the shock-ECSinterval. Analysis of variance indicated that the differences between the mean latencies of the shock-ECS groups were significant ( $F=4.53, \mathrm{df}=4 / 90, p<.01$ ).

\section{EXPERIMENT 2}

In the second experiment a slightly different procedure was used in that Ss were shocked immediately after they entered the small compartment rather than having been placed there by $E$. One effect of this change is to make the punishment response-contingent. In order to further increase the generality of results, two shock intensities and a different set of shock-ECS intervals were used.

\section{Subjects and Apparatus}

The rats, 60 day old male Sprague-Dawley, were handled and fed as in Experiment 1; the apparatus was that of Experiment 1.

Procedure

The pretreatment phase of the procedure was identical to that of Experiment 1 except that no pretreatment test trials were run. Before treatments were administered, $10 \mathrm{Ss}$ were randomly assigned to each of the cells of a 2 by 5 factorial design which combined 2 and $5 \mathrm{~mA}$ foot shock intensitiles made orthogonal to shock-ECS intervals of 0 and $10 \mathrm{sec}, 30 \mathrm{~min}, 2$ and $6 \mathrm{~h}$. The ECS electrodes were attached and S placed into the large compartment facing away from the open guillotine door. When $S$ placed all four feet into the small chamber, a 0.2 sec foot shock of $2 \mathrm{~mA}$ was delivered followed at the appropriate interval by a $0.2 \mathrm{sec} 50 \mathrm{~mA}$ ECS through ear electrodes. Except for the 0 and 10 sec groups, Ss were returned to their home cages during the shock-ECS interval. All ECSs

Table 1

Mean response latencies in sec $24 \mathrm{~h}$ after treatments for Experiment 1

\begin{tabular}{ccccccc}
\hline Normal & \multicolumn{5}{c}{ Shock-ECS Groups } & Shock \\
Control & $0.5 \mathrm{sec}$ & $10 \mathrm{sec}$ & $5 \mathrm{~min}$ & $45 \mathrm{~min}$ & $2 \mathrm{~h}$ & Control \\
15.1 & 11.4 & 13.6 & 47.9 & 63.8 & 65.0 & 74.9 \\
\hline
\end{tabular}


Table 2

Mean response latencies in $\sec 24 \mathrm{~h}$ after treatments for Experiment 2

\begin{tabular}{lllllcc}
\hline & & \multicolumn{5}{c}{ Shock-ECS Groups } \\
& & $0 \mathrm{sec}$ & $10 \mathrm{sec}$ & $30 \mathrm{~min}$ & $2 \mathrm{~h}$ & $6 \mathrm{~h}$ \\
Shock & $2 \mathrm{~mA}$ & 28.6 & 55.8 & 70.1 & 82.2 & 111.2 \\
Intensities & $5 \mathrm{~mA}$ & 23.2 & 20.6 & 55.6 & 82.2 & 99.9 \\
\hline
\end{tabular}

were delivered in the small compartment. Twentyfour $h$ after treatment Ss were returned to the large compartment and latencies for placing all four feet into the small compartment were recorded.

Results

Table 2 shows the mean latencies for entering the small chamber on the post-treatment test. The $2 \mathrm{~mA}$ shock produced slightly higher latencies than the 5 $\mathrm{mA}$ shock but an analysis of variance indicated that the difference was not significant. The interaction between shock intensities and shock-ECS intervals was also not significant.

As in Experiment 1, and contrary to the results of Chorover \& Schiller (1966) and Burěs \& Burěsová (1963), the effect of ECS on posttreatment latencies appears to be a decreasing function of the shock-ECS interval. An analysis of variance indicated that the differences between the shock-ECS groups were significant $(F=4.35$, df $=4 / 90, p<.01)$.

\section{DISCUSSION}

The procedure used by Burěs \& Burěsová (1963) and Chorover \& Schiller (1966) produced results in which ECS effects were not functionally related to shock-ECS intervals but rather were constant during many hours after learning. The results of Experiments 1 and 2 described here, however, have shown that the ECS effect on avoidance is a decreasing function of increased shock-ECS interval. These conflicting results might be attributed to procedural differences or possibly to the fact that Burěs \& Burěsová (1963) and Chorover \& Schiller (1966) used the amount of time spent in the small compartment during a standard test period as their measure of avoidance, whereas avoidance was measured by the latency of entering the shock chamber in the experiments reported here. Our results do not appear to be dependent upon the response-shock contingency, shock intensity, or the specific shock-ECS intervals employed.

\section{References}

BURĚS, J., \& BURĚSOVÁ, O. Cortical spreading depression as a memory disturbing factor. $J$. comp. physiol. Psychol,, 1963, 56, 268-272.

CHOROVER, S. L., \& SCHILLER, P. H. Reexamination of prolonged retrograde amnesia in one-trial learning. J. comp. physiol Psychol, $1966,61,34-41$.

HERIOT, J. T., \& COLEMAN, P. D. The effect of electroconvulsive shock on retention of a modified "one-trial" conditioned avoidance. J. comp. physiol Psychol, 1962, 55, 1082-1084.

McGAUGH, J. L., \& MADSEN, M. C. Amnesia and punishing effects of electroconvulsive shock. Science, 1964, 144, 182-183.

Notes

1. The experiments reported here are from a thesis submitted by the first author to the School of Graduate Studies of Queen's University in partial fulfillment of the requirements for the M.A. degree. The thesis was directed by the second author and supported by the National Research Council of Canada, Grant No. APA 68.

2. Now at San Jose State College. 